\author{
ANNA ALBIN \\ ORCID: 0000-0002-8521-6737 \\ Uniwersytet Wrocławski
}

\title{
DIAGNOZA PROBLEMÓW W ZAKRESIE GOSPODAROWANIA ODPADAMI KOMUNALNYMI W POLSCE Z JEDNOCZESNYM WSKAZANIEM KIERUNKÓW DZIAŁAŃ I ZMIAN REGULACJI PRAWNYCH W ANALIZOWANYM OBSZARZE
}

\begin{abstract}
Abstrakt: Artykuł jest próbą zdiagnozowania kluczowych problemów w systemie gospodarowania odpadami komunalnymi w Polsce. Rozwiązaniu tych problemów służy przyjmowanie racjonalnych regulacji prawnych, a także podejmowanie działań zgodnie z przyjętymi założeniami. W analizowanym obszarze istotne są mechanizmy ekonomiczne. Ponadto doskonalenie procesu gospodarowania odpadami komunalnymi powinno mieć charakter systemowy. W artykule wskazano kierunki działań i zmiany regulacji prawnych, które służą osiągnięciu celów w przedmiotowym zakresie.
\end{abstract}

Słowa kluczowe: odpady komunalne, system gospodarowania odpadami komunalnymi, odpady opakowaniowe

\section{WSTĘP}

Krajowe regulacje prawne w zakresie gospodarowania odpadami komunalnymi podlegają ciągłym zmianom. Część z nich jest związana z dostosowywaniem prawa krajowego do wymagań prawa unijnego. Wybór środków, jakimi dąży się do osiągnięcia celów określonych $\mathrm{w}$ dyrektywach odpadowych ${ }^{1}$, należy do ustawodawcy krajowego. Z dniem 1 lipca 2013 roku polski ustawodawca zobowiązał gminę do zorganizowania odbioru odpadów komunalnych od właścicieli nieruchomości ${ }^{2}$. Jednocześnie na gminę został nałożony obowiązek osiągnięcia wy-

1 Zob. w szczególności dyrektywa Parlamentu Europejskiego i Rady (UE) 2018/851 z 30 maja 2018 roku zmieniająca dyrektywę 2008/98/WE w sprawie odpadów (DZ.Urz. UE L. 150, s. 109) oraz dyrektywa Parlamentu Europejskiego i Rady (UE) 2018/852 z 30 maja 2018 roku zmieniająca dyrektywę 94/62/WE w sprawie opakowań i odpadów opakowaniowych (Dz.Urz. UE L. 150, s. 141).

${ }^{2}$ Zob. art. 6c ustawy z dnia 13 września 1996 roku o utrzymaniu czystości i porządku w gminach (Dz.U. z 2021 r. poz. 888 ze zm.), dalej: ustawa o utrzymaniu czystości i porządku w gminach. 
maganych prawem poziomów zagospodarowania odpadów ${ }^{3}$ i odpowiedzialność ${ }^{4}$ $\mathrm{z}$ tego tytułu. Powyższe stanowi istotę nowego systemu gospodarowania odpadami komunalnymi. Na przestrzeni ostatnich kilkunastu lat ${ }^{5}$ widoczna jest stała tendencja doskonalenia regulacji prawnych dotyczących systemu gospodarowania odpadami komunalnymi na poziomie krajowym. Tymczasem cele systemu nie są osiągane, a jego koszty wciąż wzrastają.

Ostatnia nowelizacja ${ }^{6}$ ustawy o utrzymaniu czystości i porządku w gminach wprowadza między innymi wyższe maksymalne stawki opłat za odpady komunalne dla nieruchomości niezamieszkałych. Zmiany dotyczą też kwestii selektywnego zbierania odpadów komunalnych. Minister Klimatu i Środowiska może wyrazić zgodę w formie decyzji na pewne odstępstwa w przedmiotowym zakresie. Umożliwiono także indywidualne rozliczanie mieszkańców budynków wielkolokalowych z obowiązku selektywnego zbierania odpadów komunalnych, a także dopłacanie gminom ze środków własnych do systemu gospodarowania odpadami komunalnymi.

Artykuł jest próbą zdiagnozowania problemów i określenia właściwych kierunków działań oraz zmian regulacji w analizowanym obszarze. Dla rozwiązania tych problemów ważne jest podejście systemowe ${ }^{7}$ i metodyczne ${ }^{8}$. Podejmowane działania faktyczne i prawne powinny tworzyć ciąg zorganizowanej aktywności ${ }^{9}$, na którą składa się planowanie, organizacja, nadzór i kontrola tych działań. Przedmiotowa analiza zostanie dokonana pod kątem skuteczności wprowadzanych rozwiązań prawnych w ujęciu systemowym, a nie konkretnych szczegółowych regulacji prawnych.

Szerzej zob. A. Goździńska, Gmina w systemie gospodarowania odpadami komunalnymi, Wrocław 2018, s. 331-347; P. Czepiel, Gospodarowanie odpadami komunalnymi w obliczu zmian wprowadzonych ustawa z 1 lipca 2011 roku, „Samorząd Terytorialny” 2013, nr 5, s. 45-61.

3 Zob. art. 3aa i 3b ustawy o utrzymaniu czystości i porządku.

${ }^{4}$ Dominuje pogląd, że jest to odpowiedzialność administracyjna (K. Kwaśnicka, Odpowiedzialność administracyjna w prawie ochrony środowiska, Warszawa 2011, s. 71). Por. W. Radecki, Ustawa o utrzymaniu czystości i porządku w gminach. Komentarz, Warszawa 2012, s. 321.

5 Od 2013 do 2021 roku.

${ }^{6}$ Zob. szerzej: przepisy ustawy z dnia 11 sierpnia 2021 roku o zmianie ustawy o utrzymaniu czystości i porządku w gminach, przepisy ustawy Prawo ochrony środowiska oraz ustawy o odpadach (podpisana przez Prezydenta Rzeczypospolitej Polskiej dnia 21 sierpnia 2021 roku). Zob. też Renata Krupa-Dąbrowska, Prezydent podpisat przepisy dotyczace wywozu śmieci - samorządy obawiają się kolejnych kosztów, https://www.prawo.pl/samorzad/oplaty-za-smieci-nizsze-nowezasady-segregacji-nieruchomosci,508867.html (dostęp: 24.09.2021).

7 System to zbiór powiązanych ze sobą elementów, jednak istotne są dopiero ich wzajemne relacje. Zob. szerzej: A. Goździńska, System gospodarowania odpadami komunalnymi, „Samorząd Terytorialny" 2009, nr 3, s. 49-60).

8 Zob. T. Kotarbiński, Traktat o dobrej robocie, Wrocław 1965, s. 86-87.

9 Zob. A. Chełmoński, Ciag działań prawnych $w$ gospodarce państwowej jako przedmiot badań - propozycja metodologiczna, „Prawo” 38, 1972, s. 22. 


\section{OGRANICZENIE KONKURENCJI I ELIMINOWANIE PODMIOTÓW NIEPOWIĄZANYCH Z GMINĄ NA RYNKU USŁUG ODBIERANIA ODPADÓW KOMUNALNYCH OD WŁAŚCICIELI NIERUCHOMOŚCI}

Zobowiązanie gminy do zorganizowania odbioru odpadów komunalnych od właścicieli nieruchomości wpłynęło na zmianę modelu rynku. Aktualnie jest to model konkurencji o rynek (na etapie przetargu) albo model rynku zamkniętego (udzielenie własnej spółce komunalnej zamówienia in house ${ }^{10}$ ). Wcześniej funkcjonował model konkurencji na rynku usług odbierania odpadów komunalnych od właścicieli nieruchomości ${ }^{11}$. Oznacza to, że została ona istotnie ograniczona ${ }^{12}$.

Obowiązujące regulacje prawne umożliwiają eliminowanie z rynku podmiotów gospodarczych niepowiązanych z gminą. Stworzony został obszar gospodarowania odpadami komunalnymi stanowiący część gospodarki komunalnej ${ }^{13}$, w którym gminne spółki na podstawie zamówienia in house mogą odbierać odpady komunalne od właścicieli nieruchomości. Aktywność podmiotów prywatnych niepowiązanych z gminą jest wówczas istotnie ograniczona ${ }^{14}$, mimo że podmioty te uzyskały wcześniej wpis do rejestru działalności regulowanej. Zadośćuczynienie warunkom formalnym i materialnym uprawnia danego przedsiębiorcę do

10 Zob. art. 6d ust. 1 ustawy o utrzymaniu czystości i porządku w gminach; zob. też wyrok WSA w Szczecinie z dnia 14 lutego 2018 roku, I SA/Sz 992/17, LEX nr 2457387. Organizacja przetargu na podstawie przepisów ustawy z dnia 11 września 2019 roku Prawo zamówień publicznych (Dz.U. z 2021 r. poz. 1129 ze zm.), dalej: Prawo zamówień publicznych jest obowiązkowa jedynie w przypadku odbierania odpadów od właścicieli nieruchomości, na których nie zamieszkują mieszkańcy, a powstają odpady komunalne, jeżeli rada gminy zdecyduje o objęciu tych nieruchomości gminnym systemem (zob. art. 6c ust 2a ustawy o utrzymaniu czystości i porządku; zob. też uchwała KIO z dnia 28 stycznia 2019 roku (KIO/KD 2/19, LEX nr 2639991).

11 Szerzej zob. A. Goździńska, Gmina a lokalny rynek ustug odbierania odpadów komunalnych, [w:] Nowe problemy badawcze w teorii publicznego prawa gospodarczego (z uwzględnieniem samorzadu terytorialnego), red. L. Kieres, Wrocław 2010, s. 75-90; zob. też A. Albin, Zmiany regulacji prawnych $w$ systemie gospodarowania odpadami komunalnymi a jego efektywność ekonomiczna, „Samorząd Terytorialny” 2020, nr 12, s. 24.

12 Na takie zagrożenie wskazywał już w 2012 roku Prezes UOKiK (zob. Raport Prezesa UOKiK, Konkurencja na polskim rynku ustug odbierania i zagospodarowania odpadów komunalnych, Warszawa 2012).

13 Obejmującej w szczególności zadania o charakterze użyteczności publicznej. Zob. E. Wojciechowski, Samorzad terytorialny w warunkach gospodarki rynkowej, Warszawa 1997, s. 19; S. Piątek, Przedsiębiorstwo użyteczności publicznej jako instytucja gospodarcza, Warszawa 1986, s. 66-67; C. Banasiński, M. Kulesza, Ustawa o gospodarce komunalnej. Komentarz, Warszawa 2002, s. 15-16; L. Kieres, Gospodarka komunalna - pojęcie, [w:] System Prawa Administracyjnego, t. 8b, Publiczne prawo gospodarcze, red. R. Hauser, Z. Niewiadomski, A. Wróbel, Warszawa 2013, s. 61-63.

14 Działają one wówczas na rynku odbierania odpadów komunalnych z nieruchomości, na których nie zamieszkują mieszkańcy, a powstają odpady, w przypadku, gdy nie są one objęte gminnym systemem gospodarowania odpadami komunalnymi. 
podjęcia działalności regulowanej. Innymi słowy, zyskuje on prawo podmiotowe do wykonywania działalności gospodarczej z mocy samego prawa, ex lege $e^{15}$.

W obszarze odbierania odpadów komunalnych od właścicieli nieruchomości nie występuje monopol naturalny związany na przykład z własnością sieci wodociągowej czy kanalizacyjnej ${ }^{16}$. Mimo to rynek odbierania odpadów komunalnych od właścicieli nieruchomości ulega postępującej monopolizacji ${ }^{17}$ na rzecz gmin i związków międzygminnych. Dzieje się tak dlatego, że to gmina w ramach obowiązujących regulacji ustawowych decyduje o modelu rynku na obszarze jej działania. To gmina wybiera współpracę z podmiotami prywatnymi czy też samodzielnie lub we współpracy z innymi gminami odbiera i zagospodarowuje odpady komunalne. Jeżeli spółce komunalnej zostanie udzielone zamówienie in house, zanika konkurencja i presja obniżania kosztów.

Racjonalność kosztów systemu gospodarowania odpadami komunalnymi powinien oceniać organ regulacyjny wyspecjalizowany w tym zakresie na podstawie szczegółowej kalkulacji kosztów oraz analizy uwarunkowań ekonomicznych całego procesu i potencjalnych skutków zmian wysokości opłaty z tego tytułu. Nadzór nad finansami gminy przez izby obrachunkowe w analizowanym aspekcie nie jest wystarczający ${ }^{18}$. Konieczna jest pogłębiona analiza kosztów uwzględniająca planowane zyski ze sprzedaży surowców wtórnych oraz prowadzenia punktów napraw i ponownego użycia produktów.

Niezależnie od powyższego należy podkreślić, że wybudowanie i eksploatacja przez gminę lub związek międzygminny własnej instalacji do przetwarzania odpadów nie jest powodem, aby eliminować konkurencję na rynku usług odbierania odpadów komunalnych od właścicieli nieruchomości. Do instalacji tej powinny zostać skierowane wyłącznie odpady niesegregowane (zmieszane). Taki nakaz

15 Szerzej zob. M. Szydło, Swoboda działalności gospodarczej, Warszawa 2005. s. 278-280; zob. też A. Borkowski, Działalność gospodarcza regulowana (kilka uwag na tle reglamentacyjnej funkcji państwa, [w:] 25 lat fundamentów wolności działalności gospodarczej. Tendencje rozwojowe, red. J. Grabowski, K. Pokryszka, A. Hołda-Wydrzyńska, Katowice 2013, s. 99-113.

16 Taryfa za wodę i ścieki podlega zatwierdzeniu przez dyrektora regionalnego zarządu gospodarki wodnej Państwowego Gospodarstwa Wodnego Wody Polskie. Jego zadaniem jest sprawdzić, czy taryfy proponowane przez samorządy są racjonalne i rzeczywiście dotyczą kosztów dostarczania wody i odprowadzania ścieków. Taryfy są cennikiem świadczonych usług, który określa ceny o charakterze sztywnym (zob. wyrok Sądu Apelacyjnego w Białymstoku z 15 listopada 2012 roku, I ACa 352/12, LEX nr 1235952).

17 Monopolizacja rynku wiąże się z zagrożeniem nadużycia pozycji dominującej, które jest bezwzględnie zakazane Szerzej zob. M. Pawełczyk, Prawo konkurencji w systemie publicznego prawa gospodarczego. Nadużywanie pozycji dominujacej, [w:] Publiczne prawo gospodarcze..., s. 637-654. Zob. też M. Szydło, Nadużywanie pozycji dominującej w prawie konkurencji, Warszawa 2010, s. $126 \mathrm{n}$.

18 Nadzór ten dotyczy kryterium legalności, a zwłaszcza zgodności z przepisami ustawy z dnia 27 sierpnia 2009 roku o finansach publicznych (Dz.U. z 2021 r. poz. 305 ze zm.); zob. też wyrok WSA w Bydgoszczy z dnia 4 września 2017 roku, I SA/Bd 736/17, LEX nr 2395945. 
wynika bezpośrednio z ustawy o odpadach ${ }^{19}$. Pozostałe odpady pochodzące z selektywnego zbierania powinny zostać zagospodarowane na zasadzie rachunku ekonomicznego. Decyzja o skierowaniu całego strumienia odpadów do instalacji komunalnej stanowiącej własność gminy czy związku międzygminnego powinna być poprzedzona rzetelną analizą ekonomiczną.

W świetle powyższego należy jeszcze raz podkreślić, że konieczne jest wzmożenie kontroli działań gminy i związków międzygminnych związanych z organizacją i wykonywaniem systemu pod kątem legalności, rzetelności i gospodarności. Organem kontrolnym w przedmiotowym zakresie jest Najwyższa Izba Kontroli. Ponadto zasadnym rozwiązaniem byłaby weryfikacja przez niezależny podmiot (wyspecjalizowany organ regulacyjny) racjonalności kosztów gospodarowania odpadami komunalnymi.

Oczywiście bardziej pożądanym rozwiązaniem jest zachowanie konkurencji na rynku usług odbierania odpadów komunalnych od właścicieli nieruchomości. Warto rozważyć przywrócenie konkurencyjności w przedmiotowym zakresie na przykład poprzez wprowadzenie warunków szczególnych (poza wymogami ustawy Prawo zamówień publicznych), kiedy możliwe jest udzielenie spółce komunalnej zamówienia in house. Spółka komunalna powinna realizować to zadanie wtedy, gdy jej oferta jest najkorzystniejsza.

\section{2. ŹLE DZIAŁAJĄCY RYNEK ODZYSKU I RECYKLINGU ODPADÓW KOMUNALNYCH}

Warunkiem osiągnięcia wymaganych prawem poziomów zagospodarowania odpadów jest stworzenie dobrze funkcjonującego rynku odzysku i recyklingu odpadów. Warunek ten nie został w Polsce dotychczas spełniony ${ }^{20}$. Przetworzenie niesegregowanych (zmieszanych) odpadów komunalnych w instalacji komunal$n^{2} j^{21}$ nie kończy procesu przetworzenia odpadów. $Z$ teoretycznego punktu widzenia w instalacji komunalnej powstają frakcje odpadów, które nadają się w całości lub w części do odzysku. Wymagają one dalszego zagospodarowania. Praktyka pokazuje jednak, że zebrane w sposób selektywny odpady przetworzone w instalacji komunalnej nie zawsze można poddać dalszym procesom odzysku lub

19 Zob. art. 29a ustawy z dnia 14 grudnia 2012 roku o odpadach (Dz.U. z 2021 r. poz. 779 ze zm.), dalej: ustawa o odpadach.

20 Od 2018 roku prawie 30\% zakładów recyklingu zostało zamkniętych (S. Sobczyk-Grygiel, Recyklerzy opowiadają się za podniesieniem maksymalnej stawki opłaty opakowaniowej [wywiad], https://serwisy.gazetaprawna.pl/ekologia/artykuly/8230803,szymon-dziak-czekan-recyklerzy-pod niesienie-maksymalnej-stawki-oplaty-opakowaniowej.html (dostęp: 25.08.2021).

${ }^{21}$ Zob. szerzej art. 35 ust 6 ustawy o odpadach. 
recyklingowi ${ }^{22}$ (nie jest to możliwe z przyczyn technologicznych lub nie jest uzasadnione z przyczyn ekonomicznych).

Każdy podmiot gospodarczy, który uzyska zezwolenie na zbieranie lub przetwarzanie odpadów, może prowadzić działalność w powyższym zakresie ${ }^{23}$. Uzyskanie zezwolenia, które jest indywidualną decyzją administracyjną o charakterze wiązanym, wymaga spełnienia warunków formalnych i materialnoprawnych ${ }^{24}$. Wydanie go na przetwarzanie lub zbieranie odpadów tworzy uprawnienie, a nie obowiązek przetwarzania lub zbierania odpadów ${ }^{25}$.

Przedsiębiorca działa w celu osiągnięcia zysku i kieruje się rachunkiem ekonomicznym. Konieczność spełnienia przez podmiot zbierający lub przetwarzający odpady szerokiego katalogu wymagań ustawowych zwiększa koszty zbierania i przetwarzania odpadów. Wskazać należy na obowiązek stworzenia wizyjnego systemu kontroli miejsc magazynowania odpadów czy opracowania operatu przeciwpożarowego ${ }^{26}$. Koszty związane są także z posiadaniem nieruchomości, na której odbywa się zbieranie lub przetwarzanie odpadów ${ }^{27}$. Istotną kwestią jest ustanowienie zabezpieczenia roszczeń przez organ wydający zezwolenie ${ }^{28}$. Wysokości stawek zabezpieczenia roszczeń są stosunkowo wysokie, co stanowi dodatkowe koszty dla podmiotu zbierającego lub przetwarzającego odpady. W przypadku, gdy przedsiębiorca, który uzyskał zezwolenie, nie wypełnia określonych w nim warunków, organ, który wydał zezwolenie, wzywa go do niezwłocznego zaniechania naruszania tych warunków ${ }^{29}$. Jeżeli przedsiębiorca mimo wezwania nadal je narusza, organ cofa zezwolenie w drodze decyzji, bez odszkodowania, i zobowiązuje do usunięcia odpadów z miejsca do tego nieprzeznaczonego ${ }^{30}$. Niestety posiadacz odpadów często nie wykonuje tego obowiązku i porzuca odpady. Ustanawianie roszczeń chroni więc przed ponoszeniem kosztów wykonania zastępczego w ramach postępowania egzekucyjnego ze środków publicznych.

Wprowadzanie ograniczeń dla podmiotów gospodarujących odpadami jest w pełni uzasadnione, pod warunkiem jednak, że zachowana zostanie zasada pro-

22 Recykling to powtórne wykorzystanie czegoś do wytworzenia nowego produktu. W prawie unijnym rozszerzono zakres definicji o „inne cele”.

${ }^{23}$ Zezwolenie jest związane z konstrukcją zakazu ogólnego, który organ administracji publicznej uchyla na wniosek zainteresowanego podmiotu (szerzej zob. K. Kiczka, Formy prawne działania administracji gospodarczej. Akty administracyjne, [w:] Publiczne prawo gospodarcze..., s. 472-478).

24 Zob. wyrok WSA w Krakowie z dnia 30 czerwca 2020 roku (II SA/Kr 155/20, LEX nr 3040546). Por. K. Strzyczkowski, Prawo gospodarcze publiczne, Warszawa 2011, s. 204.

25 Wyrok NSA z dnia 8 grudnia 2016 roku (II OSK 1911/16, LEX nr 2190747).

${ }^{26}$ Zob. art. 42 ust 4b i 4c ustawy o odpadach.

27 Zob. szerzej art. $41 \mathrm{~b}$ ustawy o odpadach.

28 Zob. szerzej art. 48a ustawy o odpadach.

29 Zob. wyrok NSA z dnia 10 marca 2020 roku (II OSK 1171/18, LEX nr 3020124).

30 Zob. wyrok WSA w Poznaniu z dnia 24 stycznia 2018 roku, II SA/Po 815/17, LEX nr 2466861; wyrok WSA w Rzeszowie z dnia 31 maja 2017 roku, II SA/Rz 1529/16, LEX nr 2436225. 
porcjonalności ${ }^{31}$. Wszystkie opisane powyżej wymagania powodują, że zbieranie, odzysk i recykling odpadów stają się coraz bardziej kosztowne. Jest to jeden z powodów, dla których branża ta nie rozwija się. Ograniczenia, na które napotykają przedsiębiorcy, powinny być adekwatne do celu, jakiemu służą. Regulacje prawne powinny wyważyć interes przedsiębiorcy, który przetwarza odpady, oraz interes publiczny, jakim jest ochrona środowiska przed odpadami ${ }^{32}$.

Powodem źle działającego rynku odzysku i recyklingu odpadów jest także brak technologii ich przetwarzania. Produkty i opakowania wykonywane są z materiałów i substancji, które trudno przetworzyć, mimo że widoczny jest postęp technologiczny. Często też przetwarzanie odpadów jest bardzo kosztowne i wówczas staje się ekonomicznie nieuzasadnione.

Podsumowując, racjonalnym kierunkiem działań jest tworzenie korzystnych warunków dla podejmowania i prowadzenia działalności gospodarczej w zakresie odzysku i recyklingu odpadów komunalnych. Równie ważne jest określanie wymogów dla wprowadzanych na rynek produktów i opakowań tak, aby w przyszłości możliwe były ich przetwarzanie.

\section{NIEDOSTATECZNE POWIĄZANIE OBOWIĄZKÓW GMINY}

W ZAKRESIE ZAGOSPODAROWANIA PAPIERU, SZKŁA, METALI

I TWORZYW SZTUCZNYCH Z DZIAŁANIAMI ZWIĄZANYMI ZE ZBIÓRKĄ I ZAGOSPODAROWANIEM ODPADÓW OPAKOWANIOWYCH PRZEZ ICH PRODUCENTÓW

Od początku stworzenia ram prawnych nowego systemu gospodarowania odpadami komunalnymi istniał problem braku zależności pomiędzy nałożonymi na gminę obowiązkami w zakresie gospodarowania odpadami komunalnym takimi, jak papier, szkło, metale i tworzywa sztuczne, a działaniami związanymi ze zbiórką i zagospodarowaniem odpadów opakowaniowych przez ich producentów.

Gminy były obowiązane osiągnąc za rok 2020 poziom przygotowania do ponownego użycia i recyklingu następujących frakcji odpadów komunalnych: papieru, metali, tworzyw sztucznych i szkła w wysokości co najmniej $50 \%$ wagowo. Gminy są obowiązane osiągnąć poziom przygotowania do ponownego użycia i recyklingu odpadów komunalnych w wysokości co najmniej $20 \%$ wagowo za rok 2021 i co roku więcej, aż do 65\% wagowo za rok 2035 i za każdy kolejny rok. $\mathrm{Z}$ kolei zgodnie $\mathrm{z}$ regulacjami ustawy z dnia 13 czerwca 2013 roku o gospodarce

31 Zob. na temat obowiązujących ustawodawcę wymogów, które wynikają z zasady proporcjonalności (T. Kocowski, Funkcje administracji gospodarczej, [w:] Publiczne prawo gospodarcze..., s. 696-697).

32 Wolność działalności gospodarczej ograniczana jest przede wszystkim na podstawie art. 22 Konstytucji RP poprzez klauzulę ,ważnego interesu publicznego”. Szerzej zob. A Żurawik, Interes publiczny w prawie gospodarczym, Warszawa 2013, s. 29. 
opakowaniami i odpadami opakowaniowym ${ }^{33}$ wprowadzający produkty w opakowaniach jest obowiązany zapewniać odzysk, w tym recykling odpadów opakowaniowych ${ }^{34}$. Ponadto zostały określone roczne poziomy recyklingu odpadów opakowaniowych pochodzących z gospodarstw domowych, które organizacja odzysku opakowań jest obowiązana uwzględniać w osiągniętych poziomach ich przetwarzania ${ }^{35}$.

Gminy odpowiadają zatem w znacznej mierze za osiągnięcie poziomów zagospodarowania papieru, szkła, metalu i tworzyw sztucznych, które stanowią w istocie odpady opakowaniowe. Od producentów opakowań i odpadów opakowaniowych gminy otrzymują nieznaczne środki na edukację ekologiczną pochodzące z opłaty produktowej. W zasadzie gminy nie współpracują z producentami opakowań w przedmiotowym zakresie. Nałożenie na gminę obowiązku osiągnięcia poziomów zagospodarowania papieru, szkła, metali i tworzyw sztucznych nie gwarantuje sukcesu. Racjonalnym rozwiązaniem jest likwidacja odpadów opakowaniowych przez ich producentów, „u źródła”. Producenci opakowań skuteczniej zapobiegaliby powstaniu tych opakowań, gdyby odpowiadali za ich przetwarzanie, bardziej dbaliby wówczas o to, aby produkty i opakowania wykonane były z materiałów i substancji, które łatwo przetworzyć. Najogólniej rzecz ujmując, wskazane jest powiazanie zadań gminy w zakresie zbierania i przetwarzania papieru, tektury, szkła, metali i tworzyw sztucznych z realizacją działań związanych ze zbiórką i zagospodarowaniem odpadów opakowaniowych przez producentów opakowań.

Właściwym kierunkiem zmian regulacji prawnych jest takie poszerzenie odpowiedzialności producentów odpadów opakowaniowych, aby w większym stopniu obciążało ich zagospodarowanie odpadów surowcowych. Unia Europejska już w 2018 roku $^{36}$ określiła zestaw narzędzi, które mają sprawić, że producenci będą uczestniczyć w kosztach selektywnego zbierania, odzysku i recyklingu odpadów oraz unieszkodliwiania odpadów powstałych z ich produktów. Instrumentem finansowym są opłaty opakowaniowe. Podmioty gospodarcze, które stosują materiały z odzysku i recyklingu, powinny być obciążone niższą opłatą opakowaniową.

Ważnym kierunkiem jest tworzenie w gospodarce obiegu zamkniętego związanego ze zwiększeniem przydatności produktów do ponownego użycia i recyklingu. Docelowo stawki opłat opakowaniowych powinny zostać zróżnicowane w zależności od faktycznych kosztów zbierania, transportu i przetwarzania odpadów. Istnieje pewne zagrożenie, że koszty przetworzenia odpadów będą przez ich pro-

33 Dalej: ustawa o gospodarce opakowaniami i odpadami opakowaniowymi (Dz.U. z 2020 r. poz. 1114).

${ }^{34}$ Zob. art. 20 ustawy o gospodarce opakowaniami i odpadami opakowaniowymi. Zob. też wyrok WSA w Gdańsku z dnia 4 października 2017 roku (II SA/Gd 464/17, LEX nr 2381656).

35 Zob. art. 20 ust 5 ustawy o gospodarce opakowaniowymi i odpadami opakowaniowym.

36 Zob. dyrektywa Parlamentu Europejskiego i Rady (UE) 2018/851 z dnia 30 maja 2018 roku zmieniającej zmieniająca dyrektywę 2008/98/WE w sprawie odpadów (Dz.Urz. UE. Z z 2018 roku L.150, s. 109). Czas implementacji dyrektywy do porządku krajowego minął 5 lipca 2021 roku. 
ducentów wliczane w cenę produktu. Pozytywnym aspektem takiego rozwiązania będzie ograniczenie konsumpcji. Część tych opłat zasili budżety gmin. W efekcie przyczyni się to do obniżenia opłaty za gospodarowanie odpadami komunalnymi.

Dostępny na stronie rządowego centrum legislacji projekt ustawy o rozszerzonej odpowiedzialności producentów ${ }^{37}$ zakłada, że gminy nadal są odpowiedzialne za zagospodarowanie papieru, tektury, szkła, metali i tworzyw sztucznych. Producenci odpadów opakowań w ramach rozszerzonej odpowiedzialności producentów będą ponosić opłatę opakowaniową przeznaczaną w $80 \%$ na finansowanie gminnych systemów gospodarowania odpadami komunalnymi ${ }^{38}$, nie mając jednocześnie wpływu na sposób i poziom zagospodarowania tych odpadów przez gminę i związki międzygminne. Ogranicza to realizację przez producentów opakowań działań związanych ze zbiórką i zagospodarowaniem odpadów opakowaniowych. Gdyby wytwórca opakowań decydował, w jaki sposób opakowania są zbierane i poddawane recyklingowi, to mógłby bardziej efektywnie włączyć surowiec z recyklingu do ponownej produkcji opakowań. Byłoby to rozwiązanie o charakterze systemowym, które tworzy mechanizm ekonomicznej odpowiedzialności producenta za jego produkty wprowadzane na rynek nie tylko w okresie użytkowania i gwarancji, ale także na etapie poużytkowym, kiedy produkt staje się odpadem.

\section{ZBYT ROZBUDOWANY SYSTEM SELEKTYWNEGO ZBIERANIA ODPADÓW KOMUNALNYCH}

Odpady komunalne powinny być zbierane i odbierane od właścicieli nieruchomości w sposób selektywny. Zorganizowanie selektywnego zbierania i odbierania odpadów komunalnych wymaga poniesienia znacznych kosztów ${ }^{39}$. W praktyce okazuje się, że koszty selektywnego zbierania i odbierania odpadów komunalnych zdecydowanie przewyższają przychody z tytułu sprzedaży surowców wtórnych i produktów powstałych w wyniku odzysku czy recyklingu odpadów. Jeżeli źle działa rynek odzysku i recyklingu odpadów, selektywne zbieranie i odbieranie odpadów nie jest racjonalne. Koszty można bowiem mnożyć w nieskończoność, a wymagane prawem poziomy zagospodarowania odpadów komunalnych nadal

37 Projekt ustawy o zmianie ustawy o gospodarce opakowaniami i odpadami opakowaniowymi oraz niektórych innych ustaw z dnia 5 sierpnia 2021 roku, www.legislacja.gov.pl (dostęp: 12.08.2021).

38 Robert Horbaczewski, Producenci opakowań zapłaca, ale recykling niepewny, https:// www.prawo.pl/biznes/rozszerzona-odpowiedzialnosc-producentow-projekt-nowelizacji,509934. html?_ga=2.199231213.210220656.1628490326-471098068.1615811760 (dostęp: 10.08.2021).

$\overline{39}$ Koszty te są elementem opłaty za gospodarowanie odpadami komunalnymi. Zob. wyrok WSA w Łodzi z dnia 4 lipca 2017 roku (I SA/Łd 344/17, LEX nr 2329922). 
nie są osiągane. Gospodarowanie odpadami komunalnymi to część gospodarki ${ }^{40}$, w której zasadniczą rolę odgrywają mechanizmy ekonomiczne. Podmioty zbierające lub przetwarzające odpady podejmują decyzję o zakończeniu działalności, gdy zaczyna ona przynosić straty. Z kolei zmniejszająca się liczba podmiotów zbierających lub przetwarzających odpady powoduje, że do całego procesu trzeba coraz więcej dopłacać ${ }^{41}$.

A zatem właściwym kierunkiem działań w zakresie selektywnego zbierania odpadów jest obniżanie jego kosztów przy jednoczesnym zwiększaniu przychodów z tytułu odzysku i recyklingu odpadów. Jeżeli rynek odzysku i recyklingu nie działa, to nie jest uzasadnione rozwijanie systemu selektywnego zbierania odpadów „u źródła”42. Obniżenie kosztów selektywnego zbierania odpadów komunalnych można osiągnąć, ograniczając ilość frakcji odpadów zbieranych i odbieranych selektywnie. Oddzielnie powinny być zbierane bioodpady, odpady zmieszane i pozostałe. Podział na kolejne frakcje powinien być uzależniony od rynku odzysku i recyklingu odpadów komunalnych, w tym dostępnych technologii przetwarzania odpadów. Wprowadzona przez ustawodawcę możliwość odstępstwa pod pewnymi warunkami od selektywnego zbierania wybranych frakcji odpadów, polegającego na łącznym zbieraniu odpadów tworzyw sztucznych, metali, opakowań wielorazowego użytku i szkła, należy ocenić pozytywnie.

\section{ZBYT MAŁY NACISK NA PRZECIWDZIAŁANIE POWSTANIU ODPADÓW}

Zgodnie z hierarchią postępowania z odpadami w pierwszej kolejności należy zapobiegać ich powstaniu ${ }^{43}$. Są to w pełni uzasadnione założenia teoretyczne, jednak nie znajdują odzwierciedlenia w praktyce. Ilość odpadów wzrasta wraz z konsumpcją i co roku jest większa ${ }^{44}$. Opłata za gospodarowanie odpadami komunalnymi nie zależy od masy rzeczywiście wytworzonych odpadów komunalnych.

40 Współzależność gospodarki, państwa i prawa wydaje się dziś bezdyskusyjna (T. Kocowski, Reglamentacja działalności gospodarczej w polskim administracyjnym prawie gospodarczym, Wrocław 2009, s. 20); zob. też E. Borkowska-Bagieńska, Prawo i gospodarka. Refleksje o prawnych instrumentach oddziaływania na gospodarke, [w:] Gospodarka, administracja, samorzad, red. H. Olszewska, B. Popowska, Poznań 1997, s. 85-95.

41 Między innymi dlatego, że zanika konkurencja.

42 Por. G. Sroczyński, Segregowanie śmieci to hipokryzja. Czy to zmieszamy, czy nie, dla planety mała różnica [wywiad], https://next.gazeta.pl/next/7,151003,27064667,segregowanie-smieci-to-hipokryzja-czy-to-zmieszamy-czy-nie.html (dostęp: 10.05.2021).

43 Zob. uzasadnienie wyroku NSA z dnia 11 września 2019 roku (II OSK 2525/17, LEX nr 2739886).

44 W 2020 roku zebrano w Polsce 13,1 mln ton odpadów komunalnych, co w porównaniu z rokiem 2019 stanowi wzrost o 2,9\%. Roczna ilość odpadów wytworzonych na jednego mieszkańca w 2020 roku wyniosła $342 \mathrm{~kg}$, co oznacza wzrost o $10 \mathrm{~kg} \mathrm{w}$ porównaniu z rokiem poprzednim 
W tym kontekście brak bodźca ekonomicznego do ograniczania ich ilości. Nie stworzono także mechanizmów gospodarczych wymuszających na producentach zapobieganie powstaniu odpadów opakowaniowych „u źródła”.

Aby zasada zapobiegania powstaniu odpadów miała zastosowanie, w pierwszej kolejności konieczne jest wprowadzenie mechanizmów ekonomicznych takich jak wspomniane już opłaty opakowaniowe. Ponadto dla opakowań wielorazowego użytku należy stworzyć system kaucji. Opakowania wielorazowe mieszkańcy gminy oddawaliby do miejsca ich zakupu, z których odbieraliby je ich producenci.

Równie ważna jest edukacja ekologiczna. Zapobieganie powstaniu odpadów powinno znaleźć odzwierciedlenie w faktycznych działaniach społeczności lokalnych. Cel ten można osiągnąć poprzez wprowadzenie opisanych wyżej mechanizmów ekonomicznych oraz wzrost świadomości ekologicznej mieszkańców gminy. Zmniejszenie ilości wytwarzanych odpadów stanowiłoby potencjał całego systemu gospodarowania odpadami komunalnymi, który w istotnej mierze przyczyniałby się do osiągania poziomów zagospodarowania odpadów komunalnych.

\section{NIEZADAWALAJĄCY POZIOM MERYTORYCZNY REALIZACJI ZADAŃ W ZAKRESIE GOSPODAROWANIA ODPADAMI KOMUNALNYMI PRZEZ GMINY}

Istotą samorządu tery torialnego jest wykonywanie zadań publicznych polegających na zaspakajaniu potrzeb wspólnoty samorządowej. Takim zadaniem gminy, określonym w ustawie jako obowiązek prawny, jest utrzymanie czystości i porząd$\mathrm{ku}$. Elementem tego zadania jest odbieranie odpadów komunalnych od właścicieli nieruchomości. To gmina organizuje selektywne zbieranie i odbieranie odpadów komunalnych od właścicieli nieruchomości. Przypisanie tego zadania gminie jako podstawowej jednostce samorządu terytorialnego jest zgodne z zasadą proporcjonalności i zasadą sprawnego działania. Dalsze zagospodarowanie selektywnie zebranych odpadów komunalnych przewyższa co do zasady możliwości organizacyjne i finansowe pojedynczej gminy. Gospodarowanie odpadami komunalnymi na poziomie gminy wymaga aktualnie merytorycznej wiedzy i doświadczenia. Tymczasem w sektorze publicznym coraz bardziej brakuje specjalistów. $Z$ tego punktu widzenia realizacja tych zadań przez podmioty prywatne niepowiązane z gminą w wyższym stopniu zapewnia profesjonalny charakter działań.

Koszty systemu gospodarowania odpadami komunalnymi, który nie działa sprawnie, wzrastają. Mieszkańcy gminy dokonują oceny organu wykonawczego gminy, biorąc pod uwagę wysokość opłaty i jakość świadczonych usług. Wójt, burmistrz lub prezydent miasta ponosi z powyższego tytułu odpowiedzialność

(www.teraz-srodowisko.pl; dostęp: 10.05.2021). Ilość wytworzonych odpadów na jednego mieszkańca w Europie jest jeszcze większa. 
polityczną w przyszłych wyborach. Dlatego też szczególnie ważna jest jawność i przejrzystość tego systemu.

System powinien się samofinansować. Stworzenie podstawy prawnej dającej możliwość dopłaty do systemu z innych źródeł budżetowych niezwiązanych z gospodarowaniem odpadami komunalnymi wcale nie jest rozwiązaniem usprawniającym system. W przypadku wzrostu kosztów pokrywane one będą de facto z innych danin publicznych. Skoro jednak będzie możliwe zwiększenie wydatków budżetowych bez podniesienia wysokości opłaty za gospodarowanie odpadami komunalnymi, kontrola społeczna zostanie w znacznym stopniu osłabiona. Takie rozwiązanie prawne nie rozwiązuje problemu, pozwala tylko ukryć nieefektywne ekonomicznie zarządzenie systemem.

\section{WNIOSKI}

W artykule zdiagnozowano i poddano analizie kluczowe problemy w obszarze gospodarowania odpadami komunalnymi ${ }^{45}$. W świetle tych rozważań można stwierdzić, że wskazane są następujące kierunki działań i związane z nimi zmiany regulacji prawnych:

1. Przeciwdziałanie monopolizacji rynku odbierania odpadów komunalnych od właścicieli nieruchomości poprzez wprowadzenie warunków szczególnych, kiedy możliwe jest udzielenie spółce komunalnej zamówienia in house;

2. Wzmożenie kontroli gmin oraz związków międzygminnych odpowiedzialnych za funkcjonowanie systemu gospodarowania odpadami komunalnymi pod kątem kryterium legalności, rzetelności i gospodarności przez Naczelną Izbę Kontroli;

3. Weryfikacja stawki opłaty za gospodarowaniem odpadami komunalnymi pod kątem racjonalności przez wyspecjalizowany organ regulacyjny w zakresie gospodarki odpadami;

4. Wprowadzanie ograniczeń dla przedsiębiorców zbierających lub przetwarzających odpady proporcjonalnie do zmierzonego celu w sposób zapewniający optymalizację kosztów ich działalności;

5. Upraszczanie systemu selektywnego zbierania i odbierania odpadów komunalnych. Ograniczenie frakcji odpadów zbieranych selektywnie w zależności od technologii i opłacalności ich przetwarzania;

6. Wprowadzenie mechanizmów ekonomicznych służących zapobieganiu powstawaniu odpadów w postaci opłat opakowaniowych oraz systemu kaucji opakowań wielorazowego użytku;

45 Nie oznacza to, że autorka nie dostrzega innych problemów w analizowanym obszarze. Nie sposób się jednak do nich odnieść w jednym artykule. 
7. Poszerzenie odpowiedzialności producentów opakowań i ich współpracy z gminami w zakresie zbierania i przetwarzania odpadów opakowaniowych;

8. Określanie wymogów dla wprowadzanych na rynek produktów i opakowań, które w przyszłości umożliwią ich racjonale przetwarzanie;

9. Podniesienie poziomu merytorycznego realizacji zadań w zakresie gospodarowania odpadami komunalnym przez gminy w oparciu o specjalistyczną wiedzę pracowników samorządowych;

10. Dążenie do samofinansowania się systemu gospodarowania odpadami komunalnymi.

\title{
DIAGNOSIS OF PROBLEMS IN THE FIELD OF MUNICIPAL WASTE MANAGEMENT IN POLAND INCLUDING AN INDICATION OF THE DIRECTIONS OF ACTIVITIES AND CHANGES IN LEGAL REGULATIONS IN THE ANALYZED AREA
}

\author{
Summary
}

The article is an attempt to diagnose key problems in the municipal waste management system in Poland. These problems can be solved by establishing rational legal regulations as well as taking actions in accordance with the adopted principles. In the analyzed area, economic mechanisms are important. Moreover, the improvement of the municipal waste management process should have a systemic character. The article points out the directions of activities and changes in legal regulations that serve to achieve the objectives in this area.

Keywords: municipal waste, municipal waste management system, packaging waste

\section{BIBLIOGRAFIA}

Albin A., Gmina w systemie gospodarowania odpadami komunalnymi, Wrocław 2018.

Albin A., Zmiany regulacji prawnych w systemie gospodarowania odpadami komunalnymi a jego efektywność ekonomiczna, „Samorząd Terytorialny” 2020, nr 12.

Banasiński C., Kulesza M., Ustawa o gospodarce komunalnej. Komentarz, Warszawa 2002.

Borkowska-Bagieńska E., Prawo i gospodarka. Refleksje o prawnych instrumentach oddziatywania na gospodarke, [w:] Gospodarka, administracja, samorzad, red. H. Olszewska, B. Popowska, Poznań 1997.

Borkowski A., Działalność gospodarcza regulowana (kilka uwag na tle reglamentacyjnej funkcji państwa), [w:] 25 lat fundamentów wolności działalności gospodarczej. Tendencje rozwojowe, red. J. Grabowski, K. Pokryszka, A. Hołda-Wydrzyńska, Katowice 2013.

Chełmoński A., Ciag działań prawnych w gospodarce państwowej jako przedmiot badań - propozycja metodologiczna, „Prawo” 38, 1972.

Czepiel P., Gospodarowanie odpadami komunalnymi w obliczu zmian wprowadzonych ustawa z 1 lipca 2011 roku, „Samorząd Terytorialny” 2013, nr 5.

Goździńska A., System gospodarowania odpadami komunalnymi, „Samorząd Terytorialny” 2009, nr 3 . 
Goździńska A., Gmina a lokalny rynek ustug odbierania odpadów komunalnych, [w:] Nowe problemy badawcze $w$ teorii publicznego prawa gospodarczego ( $z$ uwzględnieniem samorzadu terytorialnego), red. L. Kieres, Wrocław 2010.

Horbaczewski R., Producenci opakowań zapłaca, ale recykling niepewny, https://www.prawo. $\mathrm{pl} /$ biznes/rozszerzona-odpowiedzialnosc-producentow-projekt-nowelizacji,509934.html? $\mathrm{ga}=2.199231213 .210220656 .1628490326-471098068.1615811760$.

Kiczka K., Formy prawne działania administracji gospodarczej. Akty administracyjne, [w:] System Prawa Administracyjnego, t. 8b, Publiczne prawo gospodarcze, red. R. Hauser, Z.K. Niewiadomski, A. Wróbel, Warszawa 2013.

Kieres L., Gospodarka komunalna - pojęcie, [w:] System Prawa Administracyjnego, t. 8b, Publiczne prawo gospodarcze, red. R. Hauser, Z.K. Niewiadomski, A. Wróbel, Warszawa 2013.

Kocowski T., Funkcje administracji gospodarczej, [w:] System Prawa Administracyjnego, t. 8b, Publiczne prawo gospodarcze, red. R. Hausner, Z. Niewiadomski, A. Wróbel, Warszawa 2013.

Kocowski T., Reglamentacja działalności gospodarczej w polskim administracyjnym prawie gospodarczym, Wrocław 2009.

Kotarbiński T., Traktat o dobrej robocie, Wrocław 1965.

Krupa-Dąbrowska R., Prezydent podpisat przepisy dotyczace wywozu śmieci - samorzady obawiaja się kolejnych kosztów, https://www.prawo.pl/samorzad/oplaty-za-smieci-nizsze-nowe-zasadysegregacji-nieruchomosci,508867.html.

Kwaśnicka K, Odpowiedzialność administracyjna w prawie ochrony środowiska, Warszawa 2011.

Pawełczyk M., Prawo konkurencji w systemie publicznego prawa gospodarczego. Nadużyanie pozycji dominujacej, [w:] System Prawa Administracyjnego, t. 8b, Publiczne prawo gospodarcze, red. R. Hausner, Z.K. Niewiadomski, A. Wróbel, Warszawa 2013.

Piątek, S., Przedsiębiorstwo użyteczności publicznej jako instytucja gospodarcza, Warszawa 1986. Radecki W., Ustawa o utrzymaniu czystości i porządku w gminach. Komentarz, Warszawa 2012.

Raport Prezesa UOKiK, Konkurencja na polskim rynku ustug odbierania i zagospodarowania odpadów komunalnych, Warszawa 2012.

Sobczyk-Grygiel M., Recyklerzy opowiadają się za podniesieniem maksymalnej stawki opłatyopakowaniowej [wywiad], https://serwisy.gazetaprawna.pl/ekologia/artykuly/8230803,szymon-dziak-czekan-recyklerzy-podniesienie-maksymalnej-stawki-oplaty-opakowaniowej.html.

Sroczyński G., Segregowanie śmieci to hipokryzja. Czy to zmieszamy, czy nie, dla planety mała różnica [wywiad], https://next.gazeta.pl/next/7,151003,27064667,segregowanie-smieci-to-hipokryzja-czy-to-zmieszamy-czy-nie.html (dostęp: 10.05.2021).

Strzyczkowski K., Prawo gospodarcze publiczne, Warszawa 2011.

Szydło M., Nadużywanie pozycji dominującej w prawie konkurencji, Warszawa 2010.

Szydło M., Swoboda działalności gospodarczej, Warszawa 2005.

Wojciechowski E., Samorzad terytorialny w warunkach gospodarki rynkowej, Warszawa 1997.

Żurawik A., Interes publiczny w prawie gospodarczym, Warszawa 2013.

\section{ORZECZNICTWO}

Uchwała Krajowej Izby Odwoławczej z dnia 28 stycznia 2019 roku, KIO/KD 2/19, LEX nr 2639991. Wyrok NSA z dnia 8 grudnia 2016 roku, II OSK 1911/16, LEX nr 2190747.

Wyrok NSA z dnia 11 września 2019 roku, II OSK 2525/17, LEX nr 2739886.

Wyrok NSA z dnia 10 marca 2020 roku, II OSK 1171/18, LEX nr 3020124.

Wyrok Sądu Apelacyjnego w Białymstoku z 15 listopada 2012 roku, I ACa 352/12, LEX nr 1235952.

Wyrok WSA w Bydgoszczy z dnia 4 września 2017 roku, I SA/Bd 736/17, LEX nr 2395945.

Wyrok WSA w Gdańsku z dnia 4 października 2017 roku, II SA/Gd 464/17, LEX nr 2381656.

Wyrok WSA w Krakowie z dnia 30 czerwca 2020 roku, II SA/Kr 155/20, LEX nr 3040546.

Wyrok WSA w Łodzi z dnia 4 lipca 2017 roku, I SA/Łd 344/17, LEX nr 2329922.

Przegląd Prawa i Administracji 127, 2021

(C) for this edition by CNS 
Wyrok WSA w Poznaniu z dnia 24 stycznia 2018 roku, II SA/Po 815/17, LEX nr 2466861. Wyrok WSA w Rzeszowie z dnia 31 maja 2017 roku, II SA/Rz 1529/16, LEX nr 2436225. Wyrok WSA w Szczecinie z dnia 14 lutego 2018 roku, I SA/Sz 992/17, LEX nr 2457387. 